- COMMENTARY

Volume 11 Issue 32019

DOI: 10.21315/eimj2019.11.3.8

ARTICLE INFO

Submitted: 22-05-2019

Accepted: 06-08-2019

Online: $31-10-2019$

\section{Navigating Physiotherapy Competence Standards: The Triad Alignment of Key Stakeholders}

\author{
Veasuvalingam Bhavani ${ }^{1}$, Singh Devinder Kaur Ajit ${ }^{2}$, Su Fen Yew ${ }^{3}$ \\ ${ }^{1}$ Medical Education Research, Nerucastle Medicine Malaysia, \\ Fohor, MALAYSIA \\ ${ }^{2}$ Phisiotherapy Program and Center for Healthy Ageing and Wellness, \\ Faculty Health Sciences, Universiti Kebangsaan Malaysia, Selangor, \\ MALAYSIA
}

${ }^{3}$ Consulting Physiotherapist Silver Fubilee Home, Penang, MALAYSIA

To cite this article: Bhavani V, Ajit SDK, Yew SF. Navigating physiotherapy competence standards: the triad alignment of key stakeholders. Education in Medicine Journal. 2019;11(3):69-74. https://doi.org/10.21315/eimj2019.11.3.8

To link to this article: https://doi.org/10.21315/eimj2019.11.3.8

\begin{abstract}
Standards of physiotherapy practice by respective regulatory bodies and authorities is well documented. However, the triad alignment reported, and efforts taken by physiotherapy stakeholders is unclear and limited. This article aims to highlight any constructive alignment that exist between the three stakeholders namely the regulatory bodies, employers and the higher educational institutions (HEIs). Literature searched was conducted using Google Scholar using keywords on "physiotherapy standards", "clinical competence", "regulatory bodies" and "physiotherapy". Results showed evidence of physiotherapy regulatory bodies, educational institutions and healthcare employers advocating standards of physiotherapy. Physiotherapy authorities advocates the standards of physiotherapy competence, while educational institutions develop various competency assessment tools to measure the outlined standards on their physiotherapy graduate's. However, the healthcare providers' (employers) feedback on their expected employability skills is not promising. Evidence suggest discrepancy in the alignment, between these stakeholders and an improved mechanism could be proposed to ensure these standards are well communicated and integrated. Such constructive alignment is imperative in ensuring the physiotherapy workforce produced meet the current $21 \mathrm{st}$ century health care demands for-optimal patient outcome.
\end{abstract}

Keywords: Physiotherapy, Standards of practice, Regulatory

Veasuvalingam Bhavani, Newcastle Medicine Malaysia, 79200 Gelang Patah, Johor, Malaysia | E-mail: Bhavani.Veasuvalingam@newcastle.edu.my

\section{INTRODUCTION}

In order for supply of health workforce to meet the current healthcare demand, employer's perspective of health professional graduates plays a significant role (1). Understanding employers' perspectives allows a good insight into the qualities required during the delivery of healthcare programmes (2). Employability skills defined as "a set of achievements - skills, understandings and personal attributes that makes graduates more likely to gain employment and be successful in their 
chosen occupation's (1). Physiotherapy is a service rendered to the population to develop, maintain and restore maximum movement and functional ability throughout the lifespan (3). Employers perceived physiotherapy graduates needed enhancement in critical thinking, hypothesis generation, integrating theory into practice, analytical skills, prioritising problems, updating on professionalism and providing clear explanation about problems and treatments (4). Likewise, professionalism and confidence also reported as skills expected by employers (2). The onus is on universities providing physiotherapy programme, to reflect on their curriculum delivery on how to best produce graduates to meet the employer's expectations (5). These competencies needed to be conceptually analysed from educators, students and curriculum developer's context and the obligations of producing tomorrow's health workforce rest on higher educational institutions (HEIs) (2). Physiotherapy professional authorities and regulatory bodies worldwide have spelled out various significant competencies required to uphold the standards of its competent practice. The World Confederation of Physical Therapy (WCPT), being the global advisory provides guideline and advocates its standards through its policies for accreditation (6).

\section{THE WORLD CONFEDERATION OF PHYSICAL THERAPY (WCPT)}

The WCPT representing global physical therapy advocates all physical therapy educators to uphold the quality of the educational training standards (3). The WCPT provides guidelines on curricula for physical therapy programmes, continuous professional development, professional entry level education, standardised evaluation process for accreditation and further facilitate physiotherapy education especially the clinical education component. These guidelines explains physical therapy education on its university-based programme delivery with Bachelor, Masters and Doctorate entry qualification. The WCPT has clearly outlined their standards of practice over nine domains of competent to serve as a guide for all physiotherapy programmes. These nine domains are outlined in Table 1. Respective countries may modify these guidelines to their local context to fit for their institutional purpose.

\section{GLOBAL PHYSIOTHERAPY REGULATORY AND ADVOCATES}

Professional bodies from various countries have been advocating on minimum competence of performance as entry to practice by defining their core competencies as standards of practice and code of conducts $(2,3,6,7)$. The leading physiotherapy profession in United Kingdom pursue on quality health care delivery to the public through the Chartered Society of Physiotherapy (CSP) (7). Ten quality assurance (QA) standards developed to be applicable to individual members, physiotherapy team delivering services, managers or employers related to physiotherapy profession. The ten QA standards are as in Table 1. The Australian Physiotherapy Association (APA), advocates nine standards of physiotherapy practice (8) (see Table 1). These standards are cornerstone for the accreditation process of physiotherapy education in Australia. The American Physical Therapy Association (APTA) (9), has developed six core standards of practice (see Table 1), to excel in its professional practice and committed to promote optimal health through its standards of practice for physical therapy.

\section{MALAYSIAN PHYSIOTHERAPY REGULATORY AND ADVOCATES}

In Malaysia, the main regulatory body that governs the physiotherapy Diploma and Degree programme is our National Accreditation Body called Malaysian Qualification Agency (MQA) (10). MQA advocates eight Malaysian Qualification 
Frameworks (MQF) as shown in Table 1. MQA works in tandem the Allied Health Profession (AHP) Council under the AHP Act 774 in navigating quality assurance of all physiotherapy programmes in the country. The Malaysian Physiotherapy Association (MPA) has a role to play through one of its mission statement (https://www.mpa. net.my) - to deliver motivation towards professionalisation through continuous professional development and attainment of higher standards of patient care.
It acts as an advisory body for setting up services in the public and community health centre. The MPA's vision is to take vigorous accountability and enable the development of the physiotherapy profession so that Malaysian physiotherapists will be practitioners of choice among users and the other health care professionals. The association has five missions' statements and one is related to physiotherapy education stated as to steer physiotherapy education.

Table 1: The standards of physiotherapy practice across the continuum

\begin{tabular}{|c|c|c|c|c|}
\hline WCPT & $\begin{array}{l}\text { APA } \\
9 \text { core standards }\end{array}$ & $\begin{array}{l}\text { APTA } \\
6 \text { core standards }\end{array}$ & $\begin{array}{l}\text { CSP } \\
10 \text { core standards }\end{array}$ & MQA \\
\hline $\begin{array}{l}\text { Administration } \\
\text { and practice } \\
\text { management }\end{array}$ & $\begin{array}{l}\text { Standard } 1 \text { : Demonstrate } \\
\text { professional behaviour } \\
\text { appropriate to } \\
\text { physiotherapy }\end{array}$ & $\begin{array}{l}\text { Ethical/legal } \\
\text { considerations }\end{array}$ & $\begin{array}{l}\text { Autonomy and } \\
\text { accountability }\end{array}$ & $\begin{array}{l}\text { Knowledge of } \\
\text { discipline areas }\end{array}$ \\
\hline Communication & $\begin{array}{l}\text { Standard 2: Communicate } \\
\text { effectively }\end{array}$ & $\begin{array}{l}\text { Administration } \\
\text { of the physical } \\
\text { therapy service }\end{array}$ & $\begin{array}{l}\text { Delivering a safe and } \\
\text { effective service }\end{array}$ & Practical skills \\
\hline $\begin{array}{l}\text { Community } \\
\text { responsibility }\end{array}$ & $\begin{array}{l}\text { Standard 3: Access, } \\
\text { interpret and apply } \\
\text { information to } \\
\text { continuously improve } \\
\text { practice }\end{array}$ & $\begin{array}{l}\text { Patient/client } \\
\text { management }\end{array}$ & $\begin{array}{l}\text { Learning and } \\
\text { development }\end{array}$ & $\begin{array}{l}\text { Social skills and } \\
\text { responsibilities }\end{array}$ \\
\hline $\begin{array}{l}\text { Cultural } \\
\text { competence }\end{array}$ & $\begin{array}{l}\text { Standard 4: Assess the } \\
\text { client }\end{array}$ & Education & $\begin{array}{l}\text { Working in } \\
\text { partnership }\end{array}$ & $\begin{array}{l}\text { Values, attitude and } \\
\text { professionalism }\end{array}$ \\
\hline Documentation & $\begin{array}{l}\text { Standard 5: Interpret and } \\
\text { analyses the assessment } \\
\text { findings }\end{array}$ & Research & Consent & $\begin{array}{l}\text { Communication, } \\
\text { leadership and team } \\
\text { skills }\end{array}$ \\
\hline Education & $\begin{array}{l}\text { Standard 6: Develop } \\
\text { a physiotherapy } \\
\text { intervention plan }\end{array}$ & $\begin{array}{l}\text { Community } \\
\text { responsibility }\end{array}$ & $\begin{array}{l}\text { Record keeping } \\
\text { and information } \\
\text { governance }\end{array}$ & $\begin{array}{l}\text { Problem solving and } \\
\text { scientific skills }\end{array}$ \\
\hline Ethical behaviour & $\begin{array}{l}\text { Standard 7: Implement } \\
\text { safe and effective } \\
\text { physiotherapy } \\
\text { intervention(s) }\end{array}$ & - & Communication & $\begin{array}{l}\text { Information } \\
\text { management and } \\
\text { lifelong learning skills }\end{array}$ \\
\hline $\begin{array}{l}\text { Patient/client } \\
\text { management }\end{array}$ & $\begin{array}{l}\text { Standard 8: Evaluate } \\
\text { the effectiveness } \\
\text { and efficiency of } \\
\text { physiotherapy } \\
\text { intervention(s) }\end{array}$ & - & $\begin{array}{l}\text { Physiotherapy } \\
\text { management } \\
\text { and treatment }\end{array}$ & $\begin{array}{l}\text { Managerial and } \\
\text { entrepreneurship } \\
\text { skills }\end{array}$ \\
\hline \multirow[t]{2}{*}{$\begin{array}{l}\text { Personal/ } \\
\text { professional } \\
\text { development }\end{array}$} & $\begin{array}{l}\text { Standard 9: Operate } \\
\text { effectively across a } \\
\text { range of settings }\end{array}$ & - & $\begin{array}{l}\text { Evaluation of clinical } \\
\text { care services }\end{array}$ & \\
\hline & & & $\begin{array}{l}\text { Promoting, marketing } \\
\text { and advertising } \\
\text { physiotherapy } \\
\text { services and products }\end{array}$ & \\
\hline
\end{tabular}


Others are institute evidence-based practice, institute certification programme, nurture physiotherapy leaders and increase public awareness.

\section{EVIDENCE OF PHYSIOTHERAPY ASSESSMENT OF COMPETENCE}

Clinical education is the signature pedagogy in physiotherapy education. Initiatives are taken in developing clinical assessment instruments with the aim of assessing physiotherapy clinical competence in most physiotherapy bachelor programmes. The APTA team developed the Clinical Performance Indicator (CPI) with the aim to standardise physiotherapy training for all users. The APTA standards of practice guideline in its instrument development was used. Likewise, the Australian Physiotherapy Practice (APP), a validated assessment instrument to measure clinical competence (11), also used its standard documentation to serve as one of its guides in developing APP. Similarly, the Clinical Assessment Form (CAF) function as formative and summative form by the Irish, providing clear expectation for students and clinical instructors by year of study (12). This tool was pilots across four HEIs in Ireland to gain its consensus.

Clinical Competency Evaluation Instrument (CCEVI) developed by Malaysian physiotherapy educators (13) for its bachelor programme. Correspondingly, the Integrated Standardised Patient Examination (ISPE) developed for the Doctor of Physical Therapy students at the University Buffalo, New York, USA
(14). The Treatment Planning Assessment (TPA) developed with the same aim, by the academic staff at the University of South Australia 2001 to substitute patient practical examination and evaluate students' clinical reasoning process with regard to new physiotherapy patient assessment (15).

The most validated assessment instrument would be the CPI (16), APP (12) and CAF (13) respectively as it reports strong content validity, internal structure and response process. Hence, WCPT who is accountable in guiding its physiotherapy standards of practice advocates these three main instruments used as a guide in teaching, learning and assessment in physiotherapy programme by countries requiring such guidance. This is because these three-assessment instruments reported strong validity evidence in measuring what it intends to measure with good methodological process in its development.

The aim of this article is to identify alignment between three main stakeholders that is the professional bodies, health care providers as employers and the higher educational institutions in ensuring the standards of practice is well communicated across the three areas. This article reports the professional bodies who advocate these standards of practice are not clearly translated between the higher educational institutions and employers.

Albeit, strong efforts by advocators of standards of physiotherapy practice, various assessment instruments developed by HEIs to measure clinical competence $(11,12$, $13,14,15,16)$. This may have contributed

Table 2: Assessment instrument utilised to measure clinical competence

\begin{tabular}{lll}
\hline 1 & APTA & Clinical Performance Indicators (CPI) \\
2 & APA & Australian Physiotherapy Practice (APP) \\
3 & Ireland Physiotherapy Regulatory & Clinical Assessment Form (CAF) \\
4 & Universiti Kebangsaan Malaysia (UKM), Malaysia & Clinical Competency Evaluation Instrument (CCEVI) \\
5 & University of Buffalo, New York & Integrated Standardized Patient Examination (ISPE) \\
6 & University of South Australia & Treatment Planning Assessment (TPA) \\
\hline
\end{tabular}


to the employer's unmet expectation of our physiotherapy graduates. HEIs still struggles to produce the expected graduates' outcome that would fit the market demand. This has become much more apparent, with the current 21 st century healthcare demands and challenges. The discrepancy between professional regulators, employers' expectations and HEIs educational practices need to align to ensure the common goal achieved in harmonised approach (refer Figure 1).

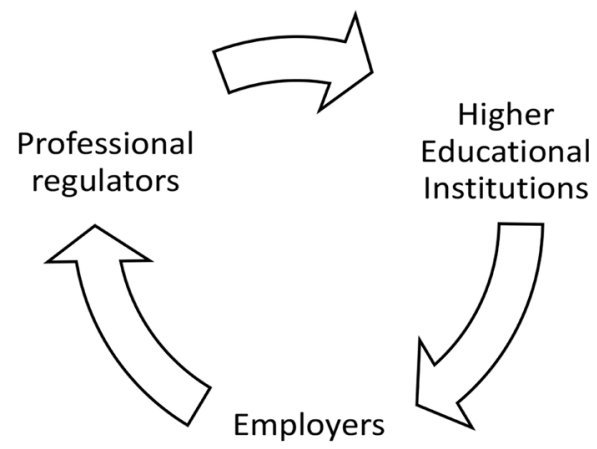

Figure 1: Alignment of the three stakeholders in producing competent physiotherapy graduates.

\section{CONCLUSION}

This collaborative alignment between three main stakeholders (employers, HEIs and professional regulatory bodies) is crucial to improve the physiotherapy competence through its teaching, learning and assessment strategies. Such critical alignment requires strategic measures to ensure these standards navigated effectively in all their processes, in the pursuit of producing quality physiotherapy workforce that would fit the current demands of healthcare practice for better patient outcome. The HEIs, employers and regulatory bodies should communicate in a systematic way forward to inculcate the clinical competence behaviour that is much sought after in the current 21 st century healthcare system. Effort need to be made to ensure the standards of clinical competence is disseminated, taught and maintained by the relevant stakeholders strategies and explore ways best possible to ensure HEIs, employers and professional regulators work in tandem to align and achieve their common vision.

\section{REFERENCES}

1. Jones M, McIntyre J, Naylor S. Are physiotherapy students adequately prepared to successfully gain employment? Physiotherapy. 2010;96(2):169-75. https:// doi.org/10.1016/j.physio.2009.11.008

2. Ramli A, Nawawi R, Chun MP. Employees' perception of employability skills needed in todays workforce among physiotherapy graduates. Procedia - Social and Behavioral Sciences. 2010;7(C):455-63.

3. WCPT. WCPT guideline for standard evaluation process for accreditation/ recognition of physical therapist professional entry level education programmes. London: WCPT; 2011a.

4. Sole G, Claydon L, Hendrick P, Hagberg J, Jonsson J, Harland T. Employers' perspectives of competencies and attributes of physiotherapy graduates: an exploratory qualitative study. NZJ Physiother. 2012;40(3):123-7.

5. Hunt A, Adamson B, Higgs J, Harris L. University education and the physiotherapy professional. Physiotherapy. 1998;84(6):264-73. https://doi.org/10.1016/ s0031-9406(05)65527-7

6. WCPT. WCPT guideline for standards of physical therapy practice. London: WCPT; 2011 b.

7. Chartered Society of Physiotherapy (CSP). Physiotherapy framework (condensed version). In: Putting physiotherapy behaviors, values, knowledge and skills into practice. London: CSP; 2011.

8. Australian Physiotherapy Association (APA). Australian standards for physiotherapy: safe and effective practice. Canberra: Australian Physiotherapy Council; 2006. 
9. American Physical Therapy Association, APTA. Today's physical therapist: a comprehensive review of a 21st-century health care profession. Alexandria, VA: American Physical Therapy Association; 2011.

10. Malaysian Qualification Agency. Malaysian Qualification Framework. 2011.

11. Dalton M, Davidson M, Keating JL. The assessment of physiotherapy practice (APP) is a reliable measure of professional competence of physiotherapy students: a reliability study. Journal of Physiotherapy. 2012;58(1):49-56. https://doi.org/10.1016/ s1836-9553(12)70072-3

12. Coote S, Alpine L, Cassidy C, Loughnane M, McMahon S, Meldrum D, O'Mahoney $M$. The development and evaluation of a common assessment form for physiotherapy practice education in Ireland. Physiotherapy Ireland. 2007;28(2):6-10.
13. Muhammad Z, Ramli A, Amat S. Validity and reliability of the clinical competency evaluation instrument for use among physiotherapy students. Clinical and Basic Research. 2014;15(2):266-74.

14. Panzarella KJ, Manyon AT. Using the integrated standardized patient examination to assess clinical competence in physical therapist students. Journal of Physical Therapy Education. 2008;22(3):24.

15. Lewis LK, Stiller K, Hardy F. A clinical assessment tool used for physiotherapy students-is it reliable? Physiotherapt Theory and Practice. 2008;24(2):121-34.

16. Roach KE, Jody SF, Francis NJ, Giles S, Nordrum JT, Delito A. Validation of the revised physical therapist clinical performance instrument (PT CPI). Physical Therapy. 2012;.92(3): 416-28. 